\section{Natural Cross-Pollination in Lettuce, Lactuca sativa L.}

SeLF-FERTILIZATION in Lactuca sativa L. is commonly regarded as being complete, although the inflorescences are visited by insects and the possibility of cross-pollination does occur ${ }^{1,2}$. Some indication that natural crossing takes place was provided by the fact that progenies raised from seed, taken from random plants grown in adjacent plots of a trial of a large number of varieties at Wellesbourne, have contained widely different proportions of off-types. An experiment was carried out in 1955, therefore, to ascertain the amount of crossing which might occur.

Two varieties were planted in each of four plots, these consisting of 15 rows of 11 plants, the odd rows and alternate plants in the even rows being of a pig. mented variety, while the remaining plants were of an unpigmented variety. Each unpigmented plant was thus surrounded by 8 pigmented ones. The gene for anthocyanin pigmentation ${ }^{3}$ behaves as a dominant in $F_{1}$.

The first plot contained two winter lettuce varieties which flower rapidly in long days ${ }^{3}$, while the second plot, which was sown at the same time as the former, contained two varieties of summer lettuce. The remaining two plots consisted of the same varieties of summer lettuce as the previous one, but were sown at three-weekly intervals. The flowering periods of all plots differed from one another, and times of flowering within plots were made to coincide by the removal of any cepitula from unpigmented plants which opened. before those of the pigmented ones. Seed collected from the unpigmented plants was sown in 1956 and the number of pigmented and of non-pigmented seedlings was recorded.

The weather in 1955 was dry and warm, encouraging insect activity; but the lettuce did not appear to have the same abundance of pollinating insects as brassica plants flowering in the vicinity. Insects most attracted by the open lettuce capitula were various species of hover-fly and a few butterflies. Bumbleand honey-bees were rarely seen on the plants. This comparative scarcity of insects suggested that the proportion of hybrids produced would be low, and this was confirmed by the results from the earlier flowering plants. The percentage of hybrids produced by the later flowering plants, however, showed a sharp increase as indicated in Table 1. It has been suggested by Mr. J. A. Dunn, of this station, that this increase was probably due to the seasonal rise in the hover-fly population, and it appeared probable that hover-flies were the main pollinators in this experiment with lettuce.

Unsuccessful attempts were made to use hover-flies as pollinators by enclosing them in muslin bags together with flowering lettuce plants; in every instance they made continual attempts to escape, and lived a maximum of only $36 \mathrm{hr}$.

\begin{tabular}{|c|c|c|c|}
\hline \multicolumn{1}{|c|}{ Table 1 } & $\begin{array}{c}\text { Mean per } \\
\text { Plot } \\
\text { No. } \\
\text { pollination }\end{array}$ \\
\hline 1 & $\begin{array}{c}\text { Varieties (pigmented } \\
\text { variety frrst) }\end{array}$ & $\begin{array}{c}\text { Flowering } \\
\text { period }\end{array}$ & $\begin{array}{c}\text { Rouge a pomme dure } \\
\text { d'hiver, Lees Im- }\end{array}$ \\
$\begin{array}{c}\text { mense } \\
\text { Mignonette, Cheshire } \\
\text { Green } \\
\text { Mignonette, Cheshire } \\
\text { Green } \\
\text { Mignonette, Cheshire } \\
\text { Green }\end{array}$ & July 18-Aug. 26 & $0 \cdot 75 \pm 0 \cdot 053$ \\
4 & Aug. 6-Sept. 8 & $0 \cdot 15 \pm 0 \cdot 009$ \\
Aug. 30-Sept. 26 & $11 \cdot 52 \pm 2 \cdot 749$ \\
\hline
\end{tabular}

The statistical analysis of the results showed that plants flowering late in the season exhibited a significant increase in the percentage of natural cross-pollination. With the exception of three plants in plot 3, cross-pollination during each of the different flowering periods was entirely at random.

National Vegetable Research Station,

L. E. WatTS

Wellesbourne, Warwick.

1 Jones, H. A., Hilgardia, 2, 13 (1927).

${ }^{2}$ Oliver, G. W., Bur. Plt. Indust. Bull. (O.S.), 167, 1 (1910).

${ }^{3}$ Bremer, A. H., and Grana, J., Gartenbauwiss., 9, 231 (1935).

\section{Sex Chromosomes in the Hop Humulus lupulus}

STuDres of meiosis in male plants of the hop Humulus lupulus have resulted in conflicting reports on the nature of the sex chromosomes. Winge ${ }^{1}$ and Jacobsen ${ }^{2}$ have described an unequal pair of sex chromosomes which Jacobsen also identified in the somatic cells of male and female plants. Sinoto ${ }^{3}$ found no heteromorphic pair, but described a chain of four sex chromosomes which he designated $X_{1} Y_{1} X_{2} Y_{2}$. No evidence was put forward in support of this interpretation. Ono 4 , however, demonstrated in $H$. lupulus var. cordifolius (the wild hop of Japan) that a quadrivalent occurred in meiotic divisions in the male, but not in the female plant. More recently ${ }^{5}$ he has described the occurrence, in a number of male varieties, of five different sex chromosome types, one of which is a homomorphic pair, two are heteromorphic pairs with different length ratios, and two are complexes of four chromosomes, also with differing length ratios.

During the 1957 season meiosis was studied, at Wye, in six male plants, five of which were seedlings from open pollination of wild Canadian or New Mexican female plants and one (No. 15) was of unknown origin. In all six a heteromorphic pair of chromosomes could be distinguished. In four of these males a quadrivalent association was found in addition to the unequal pair. Whereas the latter was a constant feature of all divisions, the quadrivalent was not present in a number of nuclei (Fig. 1,
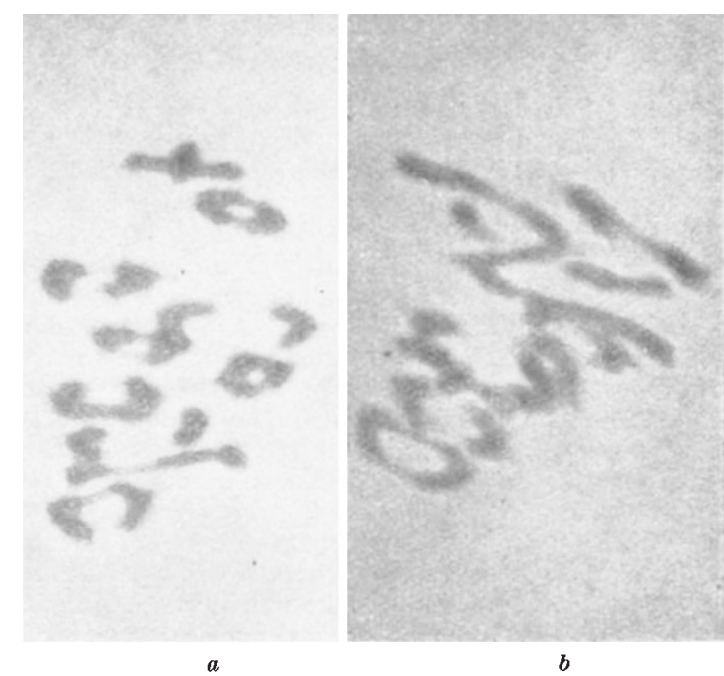

Fig. 1. Meiosis in male 321. $a$, Nucleus containing a heteromorphic pair and nine bivalents ; $b$, nucleus containing a heteromorphic pair, a quadrivalent and seven bivalents 